\title{
THE INNOVATIVE EU - THE FUTURE OF EUROPE
}

\author{
Keresztes Gábor \\ PhD. Candidate, University of West Hungary \\ E-mail: gabor.keresztes@nyme.hu
}

\begin{abstract}
In this study, I am going to compare the current innovation performance of the European Union with that of its competitors and give guidance on how to promote the flow of knowledge in Europe thereby enhancing the efficiency of the R\&D sector. These processes might be solutions to recover from the economic crisis and make progress in the 21 st century.
\end{abstract}

Keywords: innovation, European Union, Triple Helix, higher education JEL classification: I23, O31, Q55

\section{Introduction}

Nowadays we get news about that the backlog of the ,slow and old" Europe in the global competition is increasing because it is struggling with problems of competitive force. Fact is that the EU's lag is significant in certain sectors. However, from the world's three big development poles, the stability of the USA and Japan has shaken, too, and has changed since the start of the global economic crisis in 2008 rooted in the American lending processes. Meanwhile, a "new world order" is forming in the innovation sector, too. In this respect, the progressive development of the countries of the Far-East is unquestionable, mainly because of the Chinese expansion.

\section{Innovation in the European Union}

Europe's present prospects are not good, amongst others slowness, excessive bureaucracy, high state debts and budget deficit stand in the way of progress. The political leaders of Europe have already recognized the competitive disadvantage of the continent and established for this reason - inter alia - the Lisbon strategy as a solution to become competitive with the world's other economic poles. According to a corner point of the strategy, the European knowledge creation should rather become a flow of knowledge, for scientific results are rarely implemented in economy. [1]

The European Union accepted the Lisbon strategy in 2000. Pursuant to its main goal, Europe was to become the most competitive region of the world by 2010. [2] In order to reach this goal, several sub-goals were defined; one of these was the tenor of the member states to invest at least 3\% of their GDP in R\&D. However, from the EU's reports (e.g. Aho report) it became as early as in the middle of the decade clear that the targets cannot be kept. The global financial and economic crisis which broke out in 2008 has deepened the situation.

In my opinion, the necessity of change is obvious from Fig. 1, since the intensity of the R\&D expenditures of the EU is far behind of that of its competitors. Since the evolutionary economic theories it has been known that it is the innovative technological activity that is capable of leading the economies out of a crisis and encouraging economic growth. 


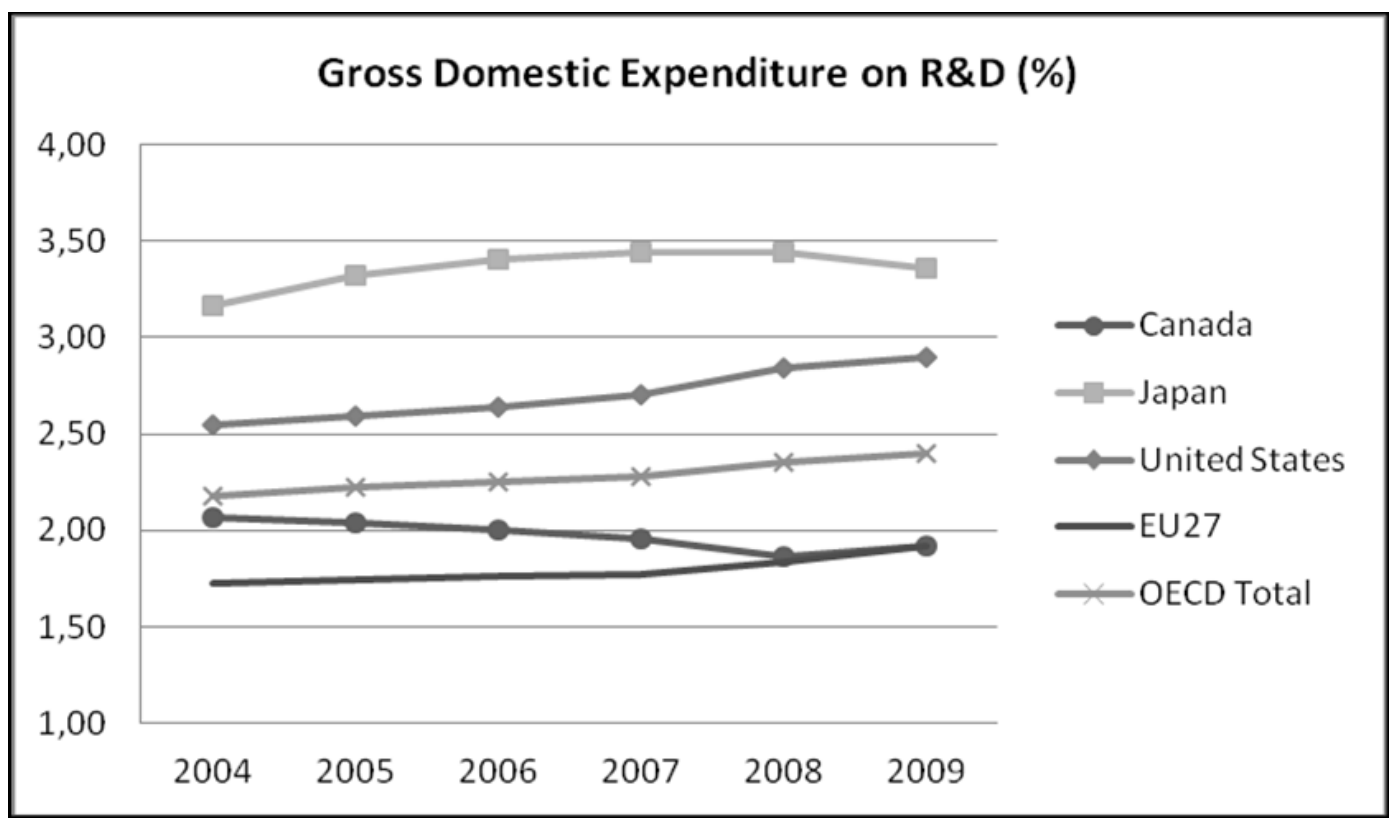

Source: [3]

Fig. 1.: Gross Domestic Expenditure on R\&D

Because of the failure of the strategy, the EU has set a new date whereby it wishes to attain the original goals by 2020 as laid down in the Europe 2020 strategy. The three main priorities of this strategy are: intelligent, sustainable and inclusive growth. [4] The headline targets of the intelligent growth by 2020 are the following:

- a minimum of 3\% GERD/GDP ratio (R\&Đ\&I) and strengthening the cooperation of these three sectors,

- to raise the employment rate of the population aged between 20-64 to 75\%,

- to reduce the share of early school leavers under $10 \%$ as well as to increase the share of the population aged between 30-34 having completed tertiary education to $40 \%$ (the same rate in the USA is $40 \%$, in Japan over 50\%) [5]

The EU aims to implement intelligent growth with the help of the following flagship initiatives:

- "Digital Agenda for Europe": high-speed internet for an increasing number of people. Final aim: broadband Internet access in all households.

- „Innovation Union”: R\&D\&I should focus on the main challenges mankind is facing: climate change, demographic problems, energy-resource efficiency and healthcare. At the same time, the process of innovation must be improved by developing the connection from the base research to dissemination in the market.

- „Youth on the move": to increase the opportunities of student study programs and traineeships abroad, to enhance the performance of education systems in order for the workforce to meet the demands of the market, to reinforce the attractiveness and national acclaim of universities and to improve education towards quality and innovation at all levels.

According to EU standpoint, the level of investments in innovation is low and a lot of citizens do not have access to novelties, they cannot make use of them. This can be traced back to economic reasons on the one hand and the lack of knowledge on the other hand. EU population has not the adequate knowledge to adopt innovation and apply it in practice, which makes it harder to decrease the competitive disadvantage. 
These targets are clearly committed to a more forcible R\&D\&I as well as appropriate and highquality trainings. The population of the European Union needs self-development in order to achieve progress in this sector. In my opinion this may have several obstacles, for example the financial, cultural and social circumstances of the different social groups, as well as their level of education. Without doubt, the key to the way out of the crisis is the enhancement of the innovational performance, its rationalization and application. European people should become more open for novelties, they should deepen and extend their knowledge and at the same time, they should be offered easy access to innovations.

Not only the European Union, but also the OECD prepared an innovation strategy for its member states. In it, they defined the following sectors as in need of development:

- empowering people to innovate,

- encouraging companies' innovation,

- fostering the creation and the flow of knowledge,

- innovation possibility should be applied for global challenges,

- improving the institutional system of innovation at political level.

One of the main reasons of the competitive disadvantage is clear: the BERD-intensity is the lowest in the EU, i.e. the contribution of the corporate sector to R\&D expenditures is the lowest here. (Fig. 2.) It is obvious that the European companies are lagging behind. As long as the share of the private sector does not grow and state orders remain to support this sector. This negative tendency will persist.

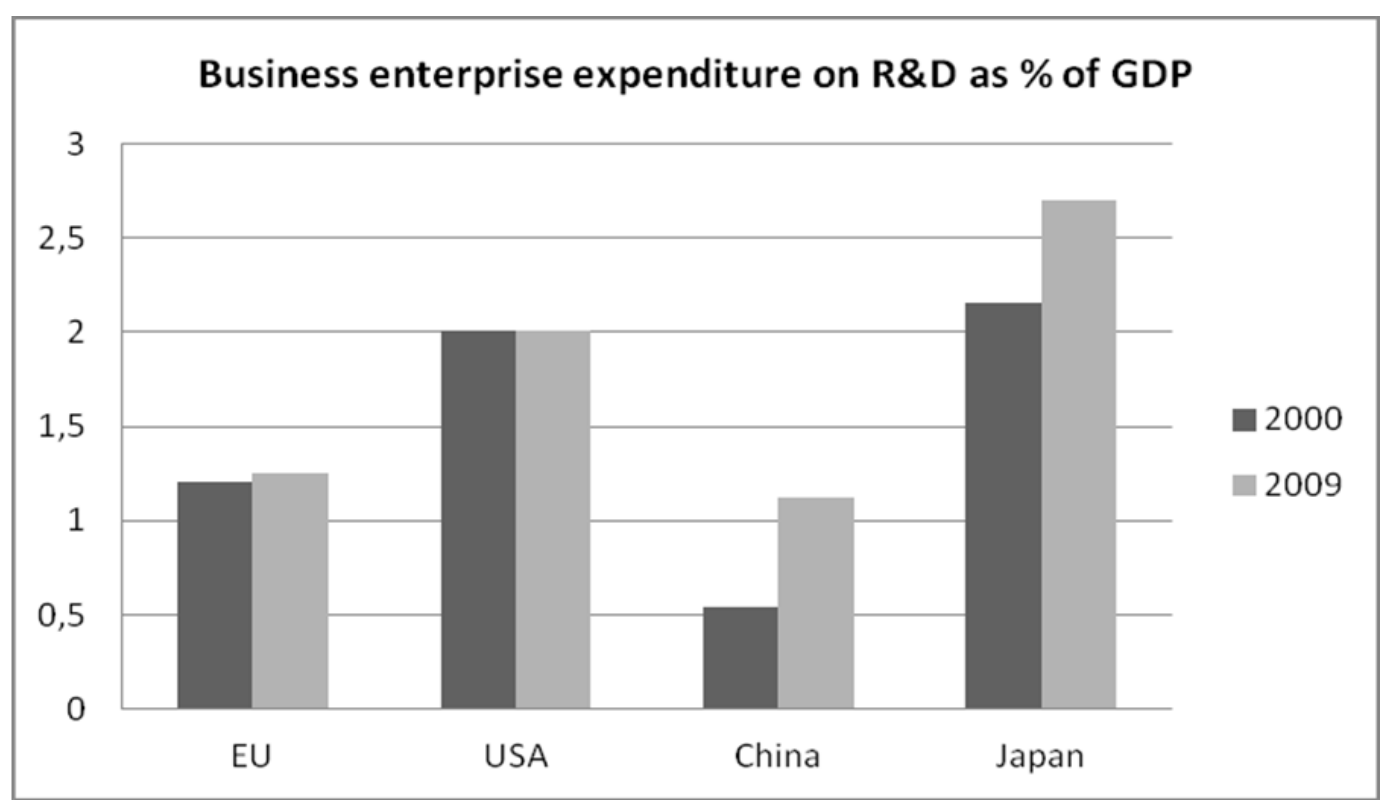

Fig. 2: Business enterprise expenditure on $R \& D$

Source: [6]

The EU shows dominance in terms of scientific activity and publications, the countries of the Far-East are way behind them. (Fig. 3.) It would be worth examining the same statistics per number of population; nevertheless, the advantage of Europe would not be then so unequivocal because of its population of half a billion being the largest. So, per number of population, Japan and mainly the USA would take in a more favorable position. 


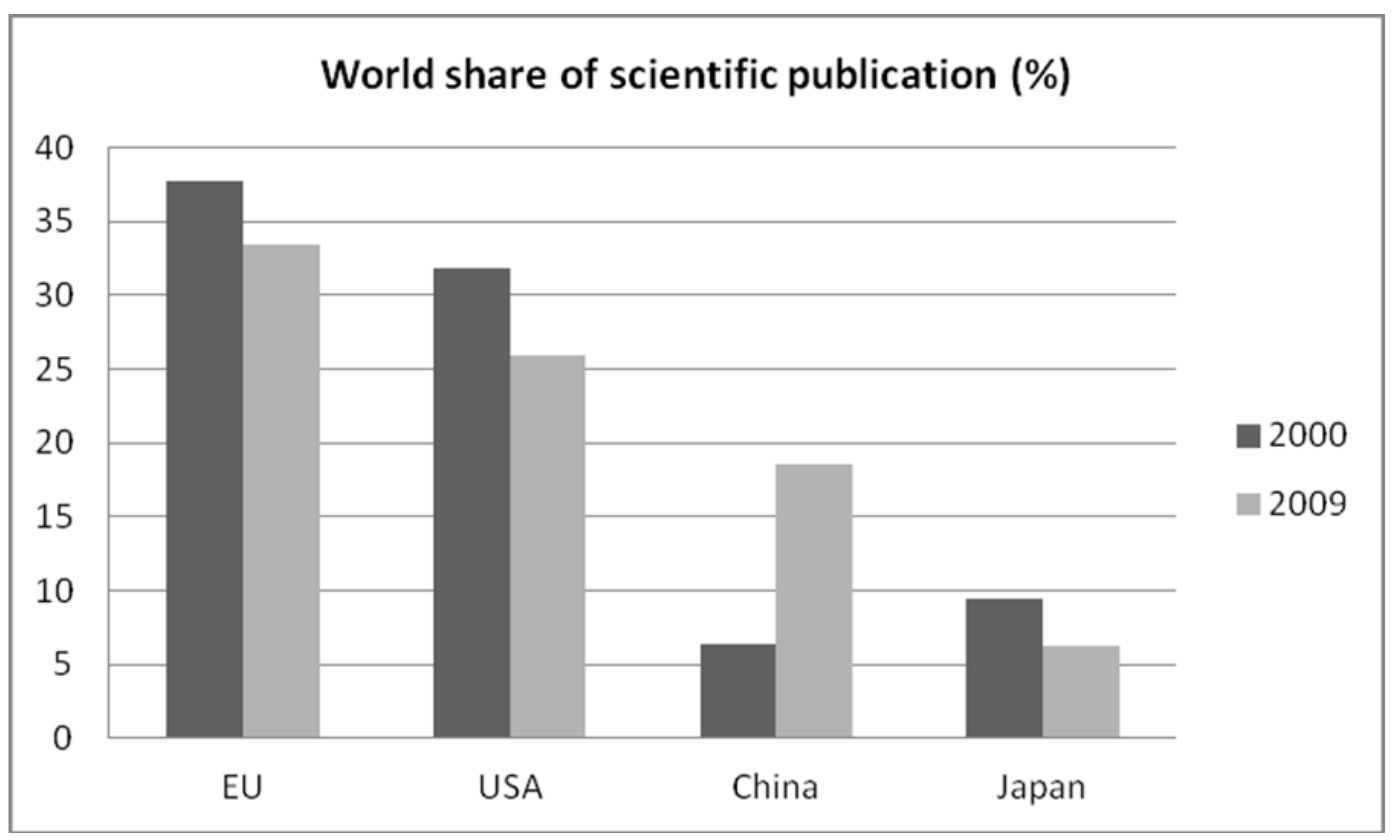

Source: [6]

Fig. 3.: World share of scientific publication

Europe is marked by a strong scientific-theoretical performance and a weak performance in practical innovation results: this is called the European paradox. According to some authors, there is a deep gap between research, and the spreading and application of knowledge, i.e. innovation - [7] in contrast to the American or the Japanese corporate research sector, where the process of innovation is much smoother. The European competitive disadvantage can not only be accounted for the low rate of R\&D investments, but also for the low propensity to entrepreneurship and innovation. Patent power is weak and so are the institutions that had been founded to build bridges between industry and science.

\section{Developing the flow of knowledge}

As the analyses have pointed out, regarding innovation, the EU has problems primarily concerning the flow and the usage of knowledge. Managing knowledge is essential to the spreading of innovation.

Some researchers think that the modern economic systems are in a state of so called 'learning economies'. [8] Pursuant to this belief, knowledge is the most important and most valuable resource that is based on learning, the most significant process for mankind and economy in the beginnings of the 21st century. Basically, knowledge can be divided into two parts: the individual knowledge, that everyone can acquire who takes part in education. This knowledge is independent of corporate practice; its level is determined by the level of education that is financed by the state as well as tax payers. Virtually everyone is free to gain this knowledge. In case of the corporate specific knowledge however, we mean the development of skills which are acquired in a cumulative way, they are based on corporate experience and become an element of knowledge while acquiring routines. [9]

A significant part of skills are the so called tacit knowledge. These elements cannot be codified and typically enough, they can only be acquired to a certain extent by way of practice. The transmission of such skills is extremely difficult for firms and requires serious efforts from the employees of the company. [10] From a practical point of view, the transmission and passing 
over of knowledge as No. 1 technological transfer, and the development of skills that enable the acquisition of knowledge can be considered as requiring largely the same costs and being of roughly the same volume. [11]

The new technology that is created as a result of the innovation presents -as effective knowledge- a significant value for certain companies. And since it bears value, it can obviously generate demand. As a result, technology becomes purchasable for virtually everyone, because it is sellable, transmittable and obtainable. Technology transfer is thus the process of the acquisition of technology and knowledge. Technology transfer is a quite complex process that incorporates the receipt of the manufacturing technology and organization, i.e. knowhow of the new products as well as the procurement of the means necessary for the production process, their putting into operation, their continuous maintenance and development, and also the organization of the production processes and production management. Further elements of the process are the production, the testing, analysis and repair of the produced product, the detection of faults during the production process, their handling and resolution. [12]

Regarding technological transfer, the literature distinguishes between two basic approaches: according to the first approach, (which is already out-of-date) technology transfer is practically a take-off that is not concerned about the development of the technological background. The recipient only gains the knowledge, copies it and uses, but does not bother about the possibilities of further efficiency and improvement. The modern approach states the opposite: according to it, in the course of technology transfer, the recipient not just takes over the technology but puts enormous efforts into further improving this valuable knowledge, and selling it later to another user, together with the added value. [13]

Thinking through this theory, some think that since technology transfer generates such processes and further developments, and because it can be purchased and sold as well as transferred between the firms, nowadays it should rather be referred to as knowledge sharing. [14]

Technology transfer can take place within and outside the company, at regional, national and international level. The most typical example of transfer within the company is the flow of knowledge between the parent company and its subsidiary. The parent company imparts the technology developed by itself to the company belonging to its own circle of interest.

Leaders of the regional and state level aim to achieve an increased flow of knowledge, involving more individuals and organizations and provide free access to the most modern knowledge elements for everybody. The flow of knowledge at the highest level is the transfer process taking place at international, transnational level. This is the most frequent case of flow of knowledge in modern companies. The transfer can be regarded as profitable, if the company adopts the international trends, improves the technology so that it can be sold later. As a result of the process, a new technology can come out of a modern technology, so the innovation can be happen. During the process of technology transfer, the company that had first transferred the technology, may receive it back from the recipient company in an improved state, thereby creating a circle that can start all over again. (Fig. 4.) This model is called bilateral technology transfer. [12] 
Source: [12]

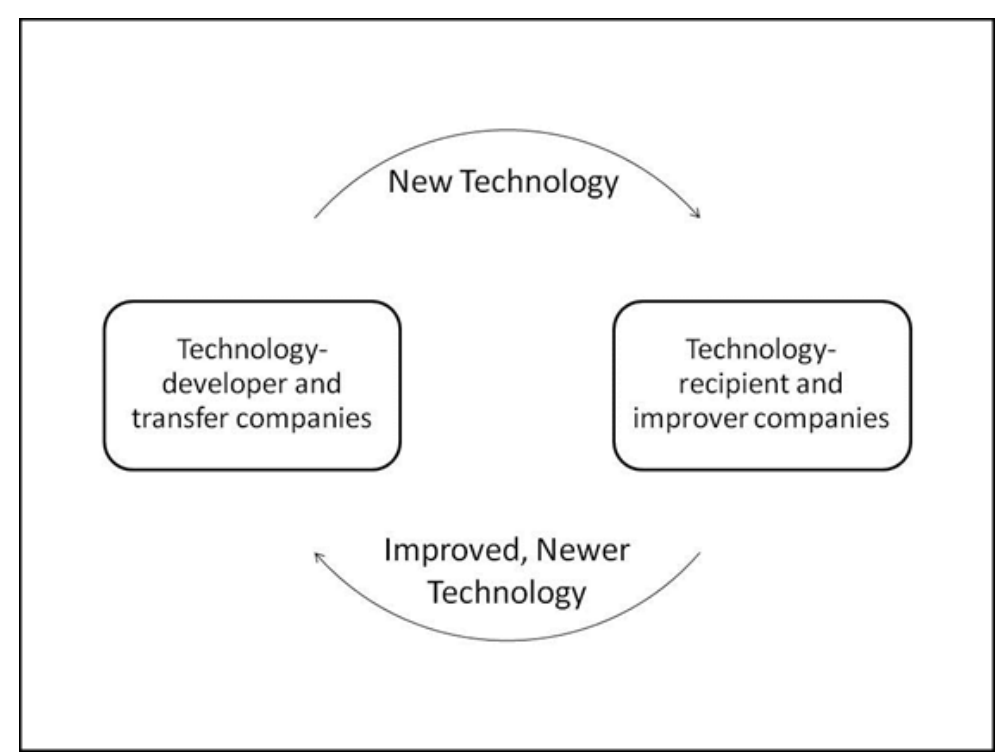

Fig. 4.: Bilateral technology transfer

\section{Enhancing the Triple Helix effect}

The efficiency of the flow of knowledge depends on how efficient the actors of the innovation process cooperate. Therefore, it is also a priority of the EU to develop this cooperation. In literature, the Triple Helix model examines the cooperation between the state (government), the companies and the higher education. (Fig. 5.)

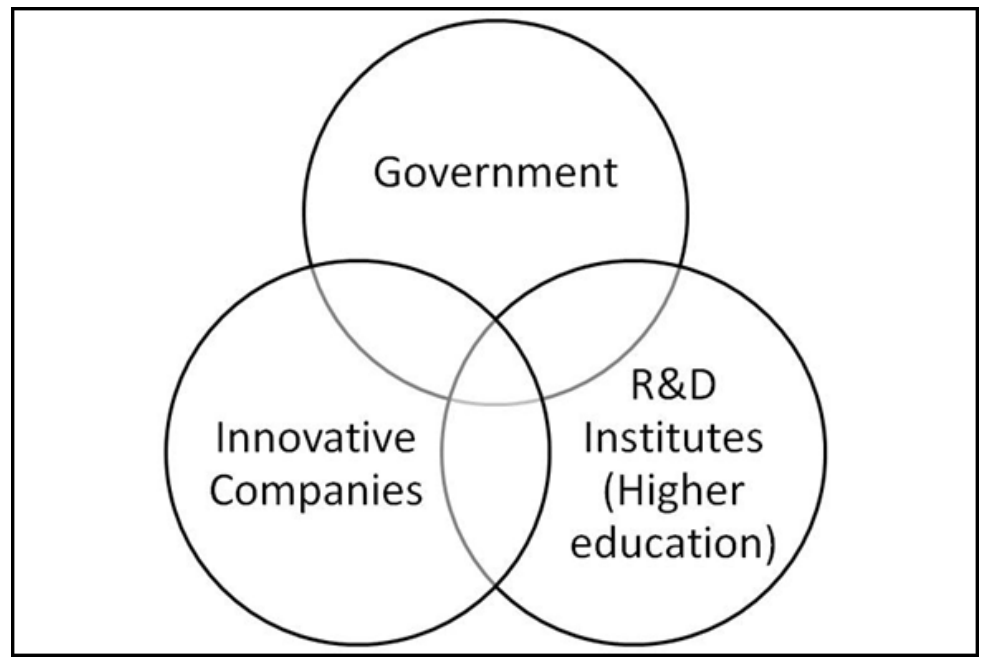

Source: [16]

Fig. 5.: The Triple Helix model

All three sectors have their own role in the model: universities are primarily responsible for the creation of new and practicable knowledge; companies (economy) have an important role in the exploitation and use of knowledge; whereas governments control the interactions in the first place. These roles may change throughout the interactions, they may merge and split; the requirements and the responsibilities could change, too. The number of universities operating also in the economic sector is increasing; such institutes establish and run science parks or incubators. Companies also carry out research in the course of development; however, base 
researches are generally state-funded. Governmental non-profit organizations take on educational and business tasks, too. [15]

The Triple Helix model is based on three main assumptions:

1. higher education institutions have an outstanding role from the three actors of the innovation process,

2. a relationship based on cooperation should be established among the actors, instead of the government prescribing the innovation policy,

3. the functions of each actors are not separated, rather all three institutes assume a role in the scope of the other two. [17]

Properly functioning European higher education institutions may thus gain in importance and become determining actors in the social and economic life. They may look after an ever better human resource, and as a new task, they may initiate new research projects and make their results adoptable by society. At present, already several governments aim to run the Triple Helix model as smooth as possible, with the common goal to establish such an innovative business environment in which the role of the state is already decreasing.

Universities have to cover the creation of knowledge, its transmission and the entire knowledge management system in the 21 st century. Beyond the base researches, they have to do applied researches, developments in laboratory, synthesis, analysis and researches based on corporate orders. To meet the requirements of the international trends however, they also need to deal with incubation (establishing and running spin-offs, research, and development and innovation projects management, participation in critical phases of corporate developments). This is all rounded off by the dissemination of the scientific and practical results (conferences, workshops, scientific debates, organizing exhibitions, publishing books and journals, organizing case study contests etc.).

\section{Conclusion}

We can say that the European Union will need substantial developments in the innovation sector in order to overcome its global competitive disadvantage. Its strategy is in harmony with this objective and both member states as Europe's citizens will have to get involved in this strategy to a great extent.

The prerequisite for future development is the improvement of the flow of knowledge. The relationship between the actors of the innovation process will have to be refined. R\&D\&I processes will need further development and increased support. Higher education has a dominant role but it will need to modernize and open up for the market. European companies should by all means emphasize innovation, whereby they can reinforce their market position in the world. The EU will have to increase its support of activities and services fostering R\&D\&I in order to increase the efficiency of technology transfer. People and the companies will need to be urged and educated for greater sensitivity to innovation. The cooperation between science and industry will have to be intensified and expanded. The practical approach to scientific results needs a change. EU policies and the member states will have to support the success of innovation processes by means of law and other regulatory measures.

In my opinion, the European Union can regain its competitiveness and strong economic potential by improving the innovation processes. 


\section{References}

1. Gács, J. [2005]: A lisszaboni folyamat: rejtélyek, elméleti problémák és gyakorlati nehézségek, MTA Közgazdaságtudományi Intézet, Mühelytanulmányok, Budapest

2. Körösi, P. [2012]: Az Európa 2020 stratégia, az EUREKA szerepe és kilátásai, MTA Közgazdaság- és Regionális Tudományi Kutatóközpont, Világgazdasági Intézet Kihívások, 205. sz., 2012. január

3. OECD [2012]: "Gross domestic expenditure on R\&D", Science and Technology: Key Tables from OECD http://www.oecd-ilibrary.org/science-and-technology/grossdomestic-expenditure-on-r-d-2012 rdxp-table-2012-1-en http://dx.doi.org/10.1787/rdxp-table-2012-1-en

4. EC: ec.europa.eu/europe2020/europe-2020-in-a-nutshell/priorities/index_hu.htm

5. EC: http://ec.europa.eu/europe2020/europe-2020-in-a-nutshell/priorities/smartgrowth/index_hu.htm

6. EC: http://ec.europa.eu/research/innovation-union/pdf/competitiveness-report/ 2011/iuc2011-full-report.pdf\#view=fit\&pagemode=none

7. Pakucs, J. - Papanek, G. (szerk.) [2009]: K+F és innováció az Európai Unióban és Magyarországon, Vállalkozók Európában, Magyar Kereskedelmi és Iparkamara, Budapest.

8. Lundvall, B. A. [1992]: National Systems of Innovation: Towards a Theory of Innovation and Interactive Learning. Printer, London

9. Dosi, G. - Malerba F. (1996): 'Organizational learning and institutional embeddedness', Organization and Strategy in the Evolution of the Enterprise, Macmillan, London. http://dx.doi.org/10.1007/978-1-349-13389-5 1

10. Winter, S. G. (1987): 'Knowledge and Competence as Strategic Assets', In: D.J. Teece (ed), The Competitive Challenge, Ballingen, Cambridge, MA

11. Cusmano, L. (2000): Technology Policy and Cooperative R\&D: the Role of relational research capacity, Druid (Danish Research Unit for Industrial Dynamics) Working Paper

12. Szalavetz, A. [1999]: Technológia transzfer, innováció és modernizáció német tulajdonban lévő feldolgozóipari cégek példáján, Budapest

13. Dahlman, C. J. - Ross Larson, B. - Westphal, L.E. [1985]: Managing Technological Development. World Bank Staff Working Papers No. 717, Washington D. C.

14. Grant, E.B. - Gregory, M.J. [1997]: Tacit knowledge, the life cycle and international manufacturing transfer, Technology Analysis \& Strategic Management Volume 9, Issue 2, pages 149-162, $1997 \mathrm{http} / / / \mathrm{dx}$. doi.org/10.1080/09537329708524276

15. Lengyel, B. [2009]: Triple Helix kapcsolatok a tudásmenedzsment szemszögéböl, letöltve:http://www.eco.u-szeged.hu/egyetemrol/tudomanyos-kozlemenyek/sztegazdasagtudomanyi/tudasmenedzsment/triple-helix-kapcsolatok

16. Etzkowitz, H. - Leydesdorff, L. [2000]: The dynamics of innovation: from National Systems and „MODE 2" to a Triple Helix of university-industry-government relations. Research Policy, 29, 2 http://dx.doi.org/10.1016/S0048-7333(99)00055-4

17. Kotsis, Á. - Nagy, I. [2009]: Az innováció diffúziója és a Triple Helix modell, Educatio folyóirat, 2009 letöltve: www.hier.iif.hu/hu/educatio_reszletes.php?id=74 